\title{
Molecular characterisation of protist parasites in human-habituated mountain gorillas (Gorilla beringei beringei), humans and livestock, from Bwindi Impenetrable National Park, Uganda
}

Matthew J. Nolan ${ }^{1 *}$, Melisa Unger ${ }^{1}$, Yuen-Ting Yeap ${ }^{1}$, Emma Rogers ${ }^{1}$, Ilary Millet ${ }^{1}$, Kimberley Harman ${ }^{1}$, Mark Fox ${ }^{1}$, Gladys Kalema-Zikusoka ${ }^{2}$ and Damer P. Blake ${ }^{1^{*}}$

\begin{abstract}
Background: Over $60 \%$ of human emerging infectious diseases are zoonotic, and there is growing evidence of the zooanthroponotic transmission of diseases from humans to livestock and wildlife species, with major implications for public health, economics, and conservation. Zooanthroponoses are of relevance to critically endangered species; amongst these is the mountain gorilla (Gorilla beringei beringei) of Uganda. Here, we assess the occurrence of Cryptosporidium, Cyclospora, Giardia, and Entamoeba infecting mountain gorillas in the Bwindi Impenetrable National Park (BINP), Uganda, using molecular methods. We also assess the occurrence of these parasites in humans and livestock species living in overlapping/adjacent geographical regions.

Results: Diagnostic PCR detected Cryptosporidium parvum in one sample from a mountain gorilla (IIdA23G2) and one from a goat (based on SSU). Cryptosporidium was not detected in humans or cattle. Cyclospora was not detected in any of the samples analysed. Giardia was identified in three human and two cattle samples, which were linked to assemblage A, B and E of G. duodenalis. Sequences defined as belonging to the genus Entamoeba were identified in all host groups. Of the 86 sequence types characterised, one, seven and two have been recorded previously to represent genotypes of Cryptosporidium, Giardia, and Entamoeba, respectively, from humans, other mammals, and water sources globally.

Conclusions: This study provides a snapshot of the occurrence and genetic make-up of selected protists in mammals in and around BINP. The genetic analyses indicated that 54.6\% of the 203 samples analysed contained parasites that matched species, genotypes, or genetic assemblages found globally. Seventy-six new sequence records were identified here for the first time. As nothing is known about the zoonotic/zooanthroponotic potential of the corresponding parasites, future work should focus on wider epidemiological investigations together with continued surveillance of all parasites in humans, other mammals, the environment, and water in this highly impoverished area.
\end{abstract}

Keywords: Zoonosis, Zooanthroponosis, Infectious disease, Cryptosporidium, Giardia, Entamoeba

\footnotetext{
* Correspondence: mnolan@rvc.ac.uk; dblake@rvc.ac.uk

'Department of Pathobiology and Population Sciences, Royal Veterinary

College, University of London, Hatfield, UK

Full list of author information is available at the end of the article
} 


\section{Background}

Zoonoses are often considered as infectious diseases (IDs) acquired by humans via (in)direct contact with animal species that act as carriers of the infective agents. However, there is increasing evidence for the transmission of IDs from humans to livestock and wildlife species [1]. Here, etiological agents of concern include viruses, bacteria and protists. For instance, the diarrhoeal disease caused by Cryptosporidium parvum, that is transmitted from cattle to humans and vice versa, is responsible for economic losses in livestock animals, particularly calves, linked to mortality, morbidity, and subsequent human (re)infections as a consequence of poor hygiene [2]. Wild animals are also at risk from diseases originating in humans, e.g. human Ebola virus [3] or Yersinia pestis [4], or domesticated animals, e.g. canine distemper virus (morbillivirus) [5]. Given the 'threatened' status of many wildlife species which are already at risk from anthropogenic activities (i.e. illegal hunting, habitat modification), the increased threat of disease transmission from humans and livestock animals, and subsequent changes to host-parasite dynamics because of smaller habitat ranges imposes unnecessary risks on their continued survival.

The mountain gorilla (Gorilla beringei beringei) is critically endangered [6], and lives in two isolated regions, the Bwindi Impenetrable National Park (BINP) in Uganda and the Virunga Volcanoes Conservation Range, bounded by Uganda, Rwanda and the Democratic Republic of Congo [7, 8]. In 1993, several mountain gorilla groups were habituated to humans to promote wildlife tourism and behavioural research. In addition to the increased human contact as a direct result of these activities, the habituation process has led to gorillas venturing outside protected regions to forage. The areas surrounding BINP are subject to extreme ecological imbalances with $300-500$ people $/ \mathrm{km}^{2}$ and high numbers of livestock, both with low-quality health services. As a result, gorilla conservation is now also threatened by the increased risk of disease transmission from humans and livestock. Precautions are required to avoid interspecies transmission of 'novel' pathogens $[9,10]$.

The accurate identification of parasites from animals and environmental samples (i.e. soil, water) underpins a holistic approach to disease control. Given the limitations of conventional microscopic methods and host origin to the specific diagnosis of many parasites (i.e. Cryptosporidium, Giardia, Cyclospora and Entamoeba [11-14]), tools based on PCR have been used to characterise samples. Genetic characterisation has benefitted our understanding of epidemiology, host and geographical ranges, and assessing the risk infected hosts pose as reservoirs for interspecies infection. Despite the availability of these molecular techniques, substantial gaps in our knowledge remain. Here, we carried out a molecular study of protists infecting mountain gorillas, livestock and humans, from sites in and around BINP. We used PCR and targeted amplicon sequencing to detect and characterise parasites. The genotypes defined here were compared with published resources to provide insights into the epidemiology of disease in and around BINP and the potential for interspecies transmission.

\section{Methods}

Bwindi impenetrable National Park, Uganda

The Bwindi Impenetrable National Park (1 ${ }^{\circ}{ }^{\prime} 50^{\prime \prime} \mathrm{S}, 2^{\circ} 39^{\prime}$ $41^{\prime \prime} \mathrm{E}$ ), Uganda, covers 32,092 ha and is located on the eastern edge of the Albertine Rift Valley, sharing a border with the protected Sarambwe forest in the Democratic Republic of Congo. The National Park was created in 1991 to protect the critically endangered mountain gorilla. The Park experiences a wet and mild climate with a mean temperature range of $11-23{ }^{\circ} \mathrm{C}$, no real dry season, and provides diverse habitats ranging from 1160 to $2706 \mathrm{~m}$ in altitude. BINP is renowned as a biodiversity hotspot (see http://whc.unesco.org/en/list/682), and is home to 340 of the critically endangered mountain gorilla. Surrounded by one of the poorest and most densely populated rural areas in Uganda with more than $300-500$ people $/ \mathrm{km}^{2}$, BINP has little possibility of a buffer zone with the surrounding agricultural landscape.

\section{Sample collection}

A total of 203 faecal deposits from Gorilla beringei beringei (mountain gorilla; $n=68$ ), Bos taurus (cattle; $n=45$ ), Capri hircus (goat; $n=57$ ), and Homo sapiens (human; $n=33$ ) were collected from locations in and around BINP during May to June 2015 (see Table 1). All faecal samples were transported to the Conservation through Public Health Laboratory (BINP, Uganda) immediately after collection and fixed with $96 \%$ ethanol in a 2:1 ratio of ethanol to faeces. All samples were sent to the Royal Veterinary College for molecular analysis.

From seven habituated gorilla groups from three different sectors of the park, samples were collected from night-nests each morning and were less than eight hours old. Duplicated samples were avoided by sampling each group only once and taking just one sample per nest. Livestock faecal deposits were collected on privately owned farms bordering BINP. Samples were collected either directly from the rectum or the ground; care was taken to collect only those parts of the faeces not in contact with the environment. Humans that inhabited villages surrounding BINP and had frequent interactions with free-ranging gorillas provided faecal samples.

\section{Isolation of genomic DNA}

Total genomic DNA was isolated from each faecal sample using a QIAamp Fast DNA Stool Mini Kit (Qiagen, 
Table 1 The total numbers of each host species sampled at each site, together with the seven Gorilla beringei beringei Groups sampled from three separate regions of BINP, and geographical coordinates

\begin{tabular}{|c|c|c|c|c|c|c|}
\hline \multirow[t]{2}{*}{ Site } & \multirow[t]{2}{*}{ Geographical coordinates } & \multicolumn{4}{|l|}{ Host species } & \multirow[t]{2}{*}{ Total } \\
\hline & & Gorilla beringei beringei & Bos taurus & Capra hircus & Homo sapiens & \\
\hline Aidah-Rugira & $00^{\circ} 58^{\prime} 26.0^{\prime \prime} \mathrm{S}, 029^{\circ} 36^{\prime} 44.0^{\prime \prime} \mathrm{E}$ & & & 6 & & 6 \\
\hline \multirow[t]{4}{*}{ Buhoma } & $00^{\circ} 58^{\prime} 34.1^{\prime \prime S}, 029^{\circ} 38^{\prime} 00.5^{\prime \prime} \mathrm{E}$ & 13 fr. Group Rushegura & & & & 13 \\
\hline & $00^{\circ} 59^{\prime} 37.9^{\prime \prime S}, 029^{\circ} 37^{\prime} 47.2^{\prime \prime} \mathrm{E}$ & 10 fr. Group Mubare & & & & 10 \\
\hline & $00^{\circ} 58^{\prime} 15.4^{\prime \prime} \mathrm{S}, 029^{\circ} 36^{\prime} 48.2^{\prime \prime} \mathrm{E}$ & & & 16 & & 16 \\
\hline & $00^{\circ} 58^{\prime} 06.4^{\prime \prime} \mathrm{S}, 029^{\circ} 37^{\prime} 00.0^{\prime \prime} \mathrm{E}$ & & & & 3 & 3 \\
\hline Bujengwe Parish & $00^{\circ} 55^{\prime} 53.5^{\prime \prime} \mathrm{S}, 029^{\circ} 40^{\prime} 33.4^{\prime \prime} \mathrm{E}$ & & & & 27 & 27 \\
\hline Kanyamisinga & $00^{\circ} 57^{\prime} 26.0^{\prime \prime} \mathrm{S}, 029^{\circ} 36^{\prime} 46.5^{\prime \prime} \mathrm{E}$ & & 15 & 6 & & 21 \\
\hline Karangara Nyakahanga & $00^{\circ} 58^{\prime} 06.4^{\prime \prime} \mathrm{S}, 029^{\circ} 37^{\prime} 00.0^{\prime \prime} \mathrm{E}$ & & & & 1 & 1 \\
\hline Kayonza Mukono & $00^{\circ} 58^{\prime} 06.4^{\prime \prime} \mathrm{S}, 029^{\circ} 37^{\prime} 00.0^{\prime \prime} \mathrm{E}$ & & & & 1 & 1 \\
\hline Kihembe Nabirehe & $00^{\circ} 58^{\prime} 06.4^{\prime \prime} \mathrm{S}, 029^{\circ} 37^{\prime} 00.0^{\prime \prime} \mathrm{E}$ & & & & 1 & 1 \\
\hline \multirow[t]{2}{*}{ Mukono, Church of Uganda } & $00^{\circ} 58^{\prime} 07.9^{\prime \prime S}, 029^{\circ} 37^{\prime} 09.2^{\prime \prime} \mathrm{E}$ & & 12 & & & 12 \\
\hline & $00^{\circ} 58^{\prime} 26.9^{\prime \prime S}, 029^{\circ} 37^{\prime} 20.0^{\prime \prime} \mathrm{E}$ & & & 19 & & 19 \\
\hline Murutojo & $00^{\circ} 58^{\prime} 25.9^{\prime \prime} \mathrm{S}, 029^{\circ} 41^{\prime 7} 7.7^{\prime \prime} \mathrm{E}$ & 14 fr. Group Habinyanja & & & & 14 \\
\hline \multirow[t]{2}{*}{ Nkwenda } & $00^{\circ} 58^{\prime} 27.5^{\prime \prime} \mathrm{S}, 029^{\circ} 36^{\prime} 55.0^{\prime \prime} \mathrm{E}$ & & 18 & & & 18 \\
\hline & $00^{\circ} 58^{\prime} 49.7^{\prime \prime S}, 029^{\circ} 36^{\prime} 50.7^{\prime \prime} \mathrm{E}$ & & & 10 & & 10 \\
\hline \multirow[t]{2}{*}{ Ruhija (East) } & $01^{\circ} 04^{\prime} 31.4^{\prime \prime S}, 029^{\circ} 46^{\prime} 59.3^{\prime \prime} \mathrm{E}$ & 8 fr. Group Bitukura & & & & 8 \\
\hline & $01^{\circ} 03^{\prime} 48.6^{\prime \prime S}, 029^{\circ} 46^{\prime} 46.2^{\prime \prime} \mathrm{E}$ & 8 fr. Group Research/Kyiaguliro & & & & 8 \\
\hline \multirow[t]{2}{*}{ South } & $01^{\circ} 05^{\prime} 39.1^{\prime \prime S}, 029^{\circ} 39^{\prime} 01.5^{\prime \prime} \mathrm{E}$ & 8 fr. Group Nkuringo & & & & 8 \\
\hline & $01^{\circ} 03^{\prime} 22.4^{\prime \prime S}, 029^{\circ} 37^{\prime} 25.8^{\prime \prime} \mathrm{E}$ & 7 fr. Group Bushaho & & & & 7 \\
\hline Total & & 68 & 45 & 57 & 33 & 203 \\
\hline
\end{tabular}

Hilden, Germany). In brief, a 500-800 $\mu \mathrm{l}$ aliquot of each sample was centrifuged at $10,000 \times g / 1 \mathrm{~m}$, the supernatant removed, $1 \mathrm{ml}$ of phosphate buffered saline added to the pellet $(0.2-0.3 \mathrm{~g})$ and the samples mixed by a vortex mixer for $10 \mathrm{~s}$. Following further centrifugation at $10,000 \times g / 1 \mathrm{~m}$, the supernatant was removed, glass beads (0.4-0.6 mm diameter) (Sigma-Aldrich, St Louis, USA) to the equivalent of 0.5 volume of the faecal pellet added, and the sample homogenised using a BeadBeater $(30,000 \times$ oscillations/min for $30 \mathrm{~s})$. Total genomic DNA was then extracted as per the manufacturer's instructions and stored at $-20^{\circ} \mathrm{C}$.

\section{PCR amplification, gel electrophoresis, sequencing, and phylogenetic analysis}

Nested PCR was used to amplify total genomic DNA. For the specific identification of Cyclospora, Cryptosporidium and Entamoeba, a portion of the small subunit of the ribosomal DNA (SSU) was amplified $(\sim 500 \mathrm{bp}$, $\sim 240 \mathrm{bp}$, and 382-429 bp, respectively). The genotypic and subgenotypic classification of Cryptosporidium was achieved using part of the $60 \mathrm{kDa}$ glycoprotein gene (gp60; 250-350 bp). For the genetic characterisation of Giardia (to the level of assemblage), portions of the triosephosphate isomerase (tpi; $\sim 530 \mathrm{bp}$ ), glutamate dehydrogenase ( $g d h ; \sim 530 \mathrm{bp})$, beta-giardin ( $b g ; \sim 511 \mathrm{bp})$, and SSU ( $292 \mathrm{bp})$ genes were amplified. PCR was carried out in a volume of $50 \mu \mathrm{l}$ containing $200 \mathrm{ng}$ of DNA template, $50 \mathrm{pmol}$ of each primer, $25 \mu \mathrm{l}$ of $2 \times \mathrm{MyTaq}^{\mathrm{Tm}} \mathrm{Mix}$ (Bioline, Taunton, USA), and made up to $50 \mu \mathrm{l}$ with DNase/RNase free $\mathrm{H}_{2} \mathrm{O}$ (ThermoFisher Scientific, Hemel Hempstead, UK). Table 2 lists the primers and cycling protocol used to amplify each gene.

Visualisation of PCR amplicons was achieved on 1.5\% $w / v$ agarose in $1 \times \mathrm{TBE}$ (Tris, boric acid, ethylenediaminetetraacetic acid [EDTA] buffer) gel stained with SafeView Nucleic Acid Stain (Novel Biological Solutions, Huntingdon, UK). In brief, $5 \mu \mathrm{l}$ of each amplicon was mixed with $1 \mu \mathrm{l}$ of $6 \times$ DNA Loading Dye (ThermoFisher Scientific) and then subjected to electrophoresis at $50 \mathrm{~V} /$ 45 min using TBE buffer (0.89 M Tris base, $0.89 \mathrm{M}$ boric acid, 0.5 M EDTA; Sigma-Aldrich). A GeneRuler Low Range DNA Ladder (ThermoFisher Scientific) was included on each gel for size comparison purposes. All PCR amplicons were purified using a QIAquick ${ }^{\circ}$ PCR Purification Kit (Qiagen), per the manufacturer's instructions. Purified amplicons were subjected to cycle sequencing reactions using ABI Ready Reaction Mix (BigDye $^{\bullet}$ Terminator v3.1 chemistry; Applied Biosystems, Foster City, USA) and the same primers employed 
Table 2 PCR primers and cycling protocols to amplify target sequences from Cryptosporidium, Cyclospora, Giardia and Entamoeba

\begin{tabular}{|c|c|c|c|c|c|c|}
\hline Parasite & PCR target & Size (bp) & Primer & Reference & Cycling protocol & Reference \\
\hline \multirow[t]{4}{*}{ Cyclospora } & \multirow[t]{4}{*}{ SSU } & \multirow[t]{2}{*}{1000} & ExCycF (forward: 5'-AATGTAAAACCCTTCCAGAGTAAC-3') & \multirow[t]{4}{*}{ [90] } & \multirow{2}{*}{$\begin{array}{l}94^{\circ} \mathrm{C} / 5 \mathrm{~min} \text {, followed by } 35 \mathrm{cycles} \\
\text { of } 94^{\circ} \mathrm{C} / 45 \mathrm{~s}, 55^{\circ} \mathrm{C} / 45 \mathrm{~s} \text { and } 72^{\circ} \mathrm{C} / \\
1 \mathrm{~min} \text {, with a final extension of } 72^{\circ} \mathrm{C} / \\
10 \mathrm{~min}\end{array}$} & \multirow[t]{4}{*}{ [91] } \\
\hline & & & ExCycR (reverse: 5'-GCAATAATCTATCCCCATCACG-3') & & & \\
\hline & & \multirow[t]{2}{*}{500} & NesCycF (forward: 5'-AATTCCAGCTCCAATAGTGTAT-3') & & \multirow{2}{*}{$\begin{array}{l}\text { Secondary amplification was achieved } \\
\text { employing identical PCR conditions to } \\
\text { those used in the primary PCR }\end{array}$} & \\
\hline & & & NesCycR (reverse: 5'-CAGGAGAAGCCAAGGTAGGCRTTT-3') & & & \\
\hline \multirow[t]{8}{*}{ Cryptosporidium } & \multirow[t]{4}{*}{ SSU } & \multirow[t]{2}{*}{ 824-864 } & XF2 (forward: 5'-GGAAGGGTTGTATTATTAGATAAAG-3') & \multirow[t]{2}{*}{ [92] } & \multirow{2}{*}{$\begin{array}{l}94^{\circ} \mathrm{C} / 5 \mathrm{~min} \text {, followed by } 35 \text { cycles of } \\
94^{\circ} \mathrm{C} / 45 \mathrm{~s}, 60^{\circ} \mathrm{C} / 45 \mathrm{~s} \text { and } 72^{\circ} \mathrm{C} / 1 \mathrm{~min}, \\
\text { with a final extension of } 72{ }^{\circ} \mathrm{C} / 10 \mathrm{~min}\end{array}$} & \multirow[t]{2}{*}{ [92] } \\
\hline & & & XR2 (reverse: 5'-AAGGAGTAAGGAACAACCTCCA-3') & & & \\
\hline & & \multirow[t]{2}{*}{298} & 18SiF (forward: 5'-AGTGACAAGAAATAACAATACAGG-3') & \multirow[t]{2}{*}{ [93] } & \multirow{2}{*}{$\begin{array}{l}94^{\circ} \mathrm{C} / 5 \mathrm{~min} \text {, followed by } 35 \mathrm{cycles} \text { of } \\
94^{\circ} \mathrm{C} / 45 \mathrm{~s}, 50^{\circ} \mathrm{C} / 45 \mathrm{~s} \text { and } 72^{\circ} \mathrm{C} / 1 \mathrm{~min} \text {, } \\
\text { with a final extension of } 72{ }^{\circ} \mathrm{C} / 10 \mathrm{~min}\end{array}$} & \multirow{2}{*}{ [93] } \\
\hline & & & 18SiR (reverse: 5'-CCTGCTTTAAGCACTCTAATTTC-3') & & & \\
\hline & \multirow[t]{4}{*}{ gp60 } & \multirow[t]{2}{*}{1000} & AL3531 (forward: 5'-ATAGTCTCCGCTGTATTC-3') & [94] & \multirow{2}{*}{$\begin{array}{l}94^{\circ} \mathrm{C} / 5 \mathrm{~min} \text {, followed by } 35 \mathrm{cycles} \text { of } \\
94{ }^{\circ} \mathrm{C} / 45 \mathrm{~s}, 50^{\circ} \mathrm{C} / 45 \mathrm{~s} \text { and } 72^{\circ} \mathrm{C} / 1 \mathrm{~min}, \\
\text { with a final extension of } 72^{\circ} \mathrm{C} / 10 \mathrm{~min}\end{array}$} & \multirow[t]{4}{*}{ [95] } \\
\hline & & & AL3535 (reverse: 5'-GGAAGGAACGATGTATCT-3') & [96] & & \\
\hline & & \multirow[t]{2}{*}{457} & AL3532 (forward: 5'-TCCGCTGTATTCTCAGCC-3') & \multirow[t]{2}{*}{ [94] } & \multirow{2}{*}{$\begin{array}{l}\text { Secondary amplification was achieved } \\
\text { employing identical PCR conditions to } \\
\text { those used in the primary PCR }\end{array}$} & \\
\hline & & & AL3533 (reverse: 5'-GAGATATATCTTGGTGCG-3') & & & \\
\hline \multirow[t]{16}{*}{ Giardia } & \multirow[t]{4}{*}{ tpi } & \multirow[t]{2}{*}{605} & AL3543 (forward: 5'-AAATTATGCCTGCTCGTCG-3') & \multirow[t]{4}{*}{ [84] } & \multirow{2}{*}{$\begin{array}{l}94^{\circ} \mathrm{C} / 5 \mathrm{~min} \text {, followed by } 35 \text { cycles of } \\
94^{\circ} \mathrm{C} / 45 \mathrm{~s}, 50^{\circ} \mathrm{C} / 45 \mathrm{~s} \text { and } 72^{\circ} \mathrm{C} / 1 \mathrm{~min}, \\
\text { with a final extension of } 72^{\circ} \mathrm{C} / 10 \mathrm{~min}\end{array}$} & [84] \\
\hline & & & AL3546 (reverse: 5'-CAAACCTITTCCGCAAACC-3') & & & \\
\hline & & 530 & AL3544 (forward: 5'-CCCTTCATCGGTGGTAACTT-3') & & Secondary amplification was achieved & \\
\hline & & & AL3545 (reverse: 5'-GTGGCCACCACTCCCGTGCC-3') & & those used in the primary PCR & \\
\hline & $b g$ & 753 & G7 (forward: 5'-AAGCCCGACGACCTCACCCGCAGTGC-3') & [63] & $94^{\circ} \mathrm{C} / 5 \mathrm{~min}$, followed by 35 cycles of & [63] \\
\hline & & & G759 (reverse: 5'-GAGGCCGCCCTGGATCTTCGAGACGAC-3') & & with a final extension of $72{ }^{\circ} \mathrm{C} / 7 \mathrm{~min}$ & \\
\hline & & 511 & bgiF (forward: 5'-GAACGAACGAGATCGAGGTCCG-3') & [97] & $95^{\circ} \mathrm{C} / 15 \mathrm{~min}$, followed by 35 cycles of & [97] \\
\hline & & & bgiR (reverse: 5'-CTCGACGAGCTTCGTGTT-3') & & with a final extension of $72^{\circ} \mathrm{C} / 7 \mathrm{~min}$ & \\
\hline & $g d h$ & 786 & Ghd1 (forward: 5'-TTCCGTRTYCAGTACAACTC-3') & [53] & $94^{\circ} \mathrm{C} / 2 \mathrm{~min}$, followed by 35 cycles of & [53] \\
\hline & & & Gdh2 (reverse: 5'-ACCTCGTTCTGRGTGGCGCA-3') & & with a final extension of $72^{\circ} \mathrm{C} / 7 \mathrm{~min}$ & \\
\hline & & 530 & Gdh3 (forward: 5'-ATGACYGAGCTYCAGAGGCACGT-3') & & Secondary amplification was achieved & \\
\hline & & & Gdh4 (reverse: 5'-GTGGCGCARGGCATGATGCA-3') & & $\begin{array}{l}\text { those used in the primary PCR } \\
\text { tholing to }\end{array}$ & \\
\hline & SSU & 497 & Gia2029 (forward: 5'-AAGTGTGGTGCAGACGGACTC-3') & [98] & $94^{\circ} \mathrm{C} / 4 \mathrm{~min}$, followed by 35 cycles of & [98] \\
\hline & & & Gia2150c (reverse: 5'-CTGCTGCCGTCCTTGGATGT-3') & & with a final extension of $72^{\circ} \mathrm{C} / 4 \mathrm{~min}$ & \\
\hline & & 292 & RH11 (forward: 5'-CATCCGGTCGATCCTGCC-3') & [99] & $94^{\circ} \mathrm{C} / 4 \mathrm{~min}$, followed by 35 cycles of & \\
\hline & & & RH4 (reverse: 5'-AGTCGAACCCTGATTCTCCGCCAGG-3') & & with a final extension of $72^{\circ} \mathrm{C} / 4 \mathrm{~min}$ & \\
\hline Entamoeba & SSU & & JVC (forward: 5'-GTTGATCCTGCCAGTATTATATG-3') & [100] & $95^{\circ} \mathrm{C} / 5 \mathrm{~min}$, followed by 40 cycles of & [100] \\
\hline & & & DSPR2 (reverse: 5'-CACTATTGGAGCTGGAATTAC-3') & & with a final extension of $72^{\circ} \mathrm{C} / 4 \mathrm{~min}$ & \\
\hline
\end{tabular}

for PCR (separately), followed by direct automated sequencing at GATC Biotech, Cologne, Germany. Comparison with corresponding electropherograms verified sequence quality and consensus sequences were constructed using the software package CLC Main Workbench v.6.9.1 (CLC bio, Aarhus, Denmark).

Basic Local Alignment Search Tool analyses (BLAST ${ }^{\oplus}$ : http://blast.ncbi.nlm.nih.gov/Blast.cgi) determined the sequence similarity of genetic data determined herein (GenBank Accession nos. KY658103-KY658190; Additional file 1: Table S1). Phylogenetic analysis was used to visualise relationships among Entamoeba sequence types defined here and those of 17 recognised species and 11 published ribosomal lineages, because of criteria defined by Jacob et al. [13]. Sequences were aligned using the software MUSCLE version 3.7 [15, 16] with ClustalW sequence weighting and UPGMA clustering for iterations 1 and 2. The resultant alignment was adjusted manually using the software BioEdit [17]. Phylogenetic analysis was conducted by Bayesian inference (BI) using Monte Carlo Markov Chain analysis in MrBayes 3.1.2 [18, 19]. The likelihood parameters set for BI analysis were based on the Akaike Information Criteria corrected for small sample sizes (AICc) [20] in jModelTest2 [21]. For the SSU data, we employed the general time-reversible model of evolution with a 
gamma distribution $(\mathrm{GTR}+\Gamma)$. Posterior probabilities (pp) were calculated via 1000,000 generations, utilising four simultaneous tree-building chains, with every 100th tree saved. At this point, the standard deviation of split frequencies was $<0.01$, and the potential scale reduction factor approached 1. A 50\% majority rule consensus tree was constructed based on the final $75 \%$ of trees generated by $\mathrm{BI}$.

\section{Results}

Cryptosporidium, Giardia and Entamoeba were detected in individual faecal samples from mountain gorillas, humans, and livestock from in and around BINP, while Cyclospora was not detected in any of the samples analysed (see Table 3). PCR detected three concurrent infections: one cattle from Kanyamisinga had Giardia (KY658189) and Entamoeba (KY658126); one goat from Mukono Church of Uganda had Cryptosporidium (KY658104) and Entamoeba (KY658147); and, a gorilla from South, Group Nkuringo had Cryptosporidium (KY658103) and Entamoeba (KY658168).

\section{Appraisal of sequence data, parasite identity and prevalence of infection Cryptosporidium}

We conducted sequence analyses of all gp60 and SSU amplicons ( $n=20$ and 1 , respectively) following PCR. These analyses identified amplicons from two of 20 (10\%) faecal DNA samples to represent species and genotypes of Cryptosporidium. One sample was characterised at gp60 (KY658103) and the other at SSU (KY658104); no sample was successfully characterised at both genes. The remaining 18 amplicons were identified as false positives (various bacteria) and are not considered further.
Comparison of the unique gp60 and SSU sequence types determined herein with information available in the GenBank database inferred Cryptosporidium parvum from 1.5\% of 68 gorillas (based on gp60) and 1.7\% of 57 goats (based on SSU) tested. For the single individual faecal sample test positive in PCR for gp60, we characterised this isolate as genotype IId, subgenotype IIdA23G2, using the system of nomenclature proposed previously [22, 23].

\section{Giardia}

Sequencing of all tpi $(n=47), g d h(n=24), b g(n=3)$, and SSU $(n=5)$ test-positive PCR amplicons from 47 samples (nine from gorillas, 15 from humans and 23 from livestock) identified five samples to contain Giardia isolates representing a single genetic assemblage (A, B or E) of G. duodenalis. No sample represented mixed assemblage populations based on direct sequence comparisons. The remaining 42 samples were identified as false positive 'bacteria' or failed to sequence. For the five mono-assemblage samples, our analyses defined two distinct genotypes for tpi (represented by KY658189 and KY658190) and SSU (KY658186 and KY658187, and KY658188), and three genotypes for $g d h$ and $b g$ (KY658183-KY658185 and KY658180-KY658182, respectively). Comparison of these ten sequence types with information available in GenBank inferred G. duodenalis assemblage $\mathrm{A}$ in one of three (33\%) individual faecal samples from humans from Buhoma and one of 15 (6.6\%) cattle from Kanyamisinga; G. duodenalis assemblage B was inferred from two of 27 (7.4\%) individual faecal samples from humans from Bujengwe Parish; and, G. duodenalis assemblage $\mathrm{E}$ was inferred from one of 12 $(8.3 \%)$ individual faecal samples from cattle from

Table 3 The numbers of hosts test-positive for species of Cryptosporidium, Giardia, Entamoeba and Cyclospora, and the number of mixed infections

\begin{tabular}{|c|c|c|c|c|c|c|c|c|}
\hline \multirow[t]{2}{*}{ Host species } & \multirow{2}{*}{$\begin{array}{l}\text { No. of samples } \\
\text { examined }\end{array}$} & \multicolumn{6}{|c|}{ No. of positives (prevalence) } & \multirow[b]{2}{*}{ No. of mixed infections } \\
\hline & & $\begin{array}{l}\text { Cryptosporidium } \\
\text { parvum }\end{array}$ & $\begin{array}{l}\text { Giardia } \\
\text { duodenalis }\end{array}$ & $\begin{array}{l}\text { Entamoeba } \\
\text { bovis }^{\mathrm{a}}\end{array}$ & $\begin{array}{l}\text { Entamoeba } \\
\text { colia }^{\mathrm{a}}\end{array}$ & $\begin{array}{l}\text { Entamoeba } \\
\text { hartmanni }^{\mathrm{a}}\end{array}$ & Cyclospora & \\
\hline Gorilla beringei beringei & 68 & $1(1.5 \%)$ & & & $5(7.4 \%)$ & $33(48.5 \%)$ & & $\begin{array}{l}1 \text { (Cryptosporidium } \\
\text { parvum and Entamoeba } \\
\text { hartmanni) }\end{array}$ \\
\hline Bos taurus & 45 & & $2(4.4 \%)$ & $36(80 \%)$ & & & & $\begin{array}{l}1 \text { (Giardia duodenalis All } \\
\text { and Entamoeba bovis) }\end{array}$ \\
\hline Capra hircus & 57 & $1(1.7 \%)$ & & $34(60 \%)$ & & & & $\begin{array}{l}1 \text { (Cryptosporidium } \\
\text { parvum and Entamoeba } \\
\text { bovis) }\end{array}$ \\
\hline Homo sapiens & 33 & & $3(9.1 \%)$ & & $3(9.1 \%)$ & & & \\
\hline Totals & 203 & $2(1.0 \%)$ & $5(2.5 \%)$ & 70 & $8(3.9 \%)$ & 33 (16.3\%) & 0 & 3 \\
\hline
\end{tabular}

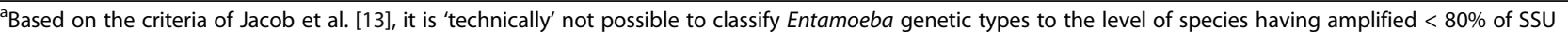
gene. However, based on initial sequence comparisons, and our phylogenetic analysis, we interpret sequence data with caution and classify Entamoeba samples as variants of E. bovis, E. coli or E. hartmanni 
Mukono, Church of Uganda. Giardia was not detected in samples from mountain gorillas or goats by PCR.

\section{Entamoeba}

Sequence analyses of all SSU amplicons $(n=111)$ identified the same number of faecal DNA samples to represent species/genotypes of Entamoeba. Comparison of the 74 unique SSU sequence types determined herein with information available in the GenBank database inferred the sequences with GenBank accession numbers KY658141 and KY658143 were identical to FN666250 and FN666252, respectively, for Entamoeba bovis, from $7.0 \%$ of 57 goats tested.

A further 72 new sequence types (GenBank accession nos. KY658105-KY658140, KY658142, KY658144KY658179) were recorded during the present investigation. Two sequence types (KY658179 and KY658178), which differed by one and three nucleotides (1\% over $630 \mathrm{bp}$ ) from a sequence of E. coli (FR686364), were each recorded in $3.0 \%$ of 33 human samples tested. A third sequence type (KY658177), which was 26 nucleotides different ( $4 \%$ over $631 \mathrm{bp}$ ) from a second $E$. coli sequence (AB4444953), was also recorded from 3.0\% of humans tested. This same sequence type (KY658157) was detected in $1.5 \%$ of 68 gorillas tested, and is the only instance where a sequence type was shared between/ among species. In the remaining 37 gorilla samples that tested positive for Entamoeba, four sequence types (KY658172, KY658155-KY658157) from five individuals, which are $20-27$ nucleotides different (3-5\% over $580 \mathrm{bp}$ ) from a sequence of $E$. coli (AB4444953), were recorded in $7.4 \%$ of 68 gorillas tested. Among these four sequence types, there are 2-7 nucleotide differences. The remaining 32 gorilla faecal samples contained Entamoeba samples with 19 different sequence types (KY658154, KY658158KY658171, KY658173-KY658176) that differed from each other by 1-18 nucleotide differences $(0.2-3.3 \%$ over $539 \mathrm{bp}$ ), and are 6-16 nucleotides different (1-3\% over 539 bp) from a sequence of E. hartmanni (AF149907), originally reported from humans. From cattle, 29 sequence types (KY658105-KY658133) were defined from 36 individual faecal samples. These sequences differed by $1-51$ nucleotides $(0.2-9.4 \%$ over $545 \mathrm{bp})$ from each other, and by $15-27,1-17$, and $4-13$ nucleotides (3-5\%, $1-3 \%$, and $1-2 \%$ over $545 \mathrm{bp})$ from three sequences of $E$. bovis (FN666249-FN666251, respectively), originally reported from cattle (FN666249) and sheep (FN666250 and FN666251). Finally, from goats, 18 new sequence types (KY658134-KY658153) were defined from 30 individual faecal samples, which differed by 1-53 nucleotides (0.2$9.7 \%$ over $546 \mathrm{bp}$ ) from each other. These sequence data are $4-7,14-34$, and $2-6$ nucleotides different (1\%, 3-6\%, and $1 \%$ over $546 \mathrm{bp}$ ) from three sequences of $E$. bovis (FN666250-FN666252, respectively), originally reported from sheep (FN666250 and FN666251) and caribou (FN666252).

The novel Entamoeba sequences defined here were aligned with 39 reference sequences obtained from GenBank. These reference sequences represented 17 recognised species and 11 published ribosomal lineages. All sequences were aligned across 611 positions. Phylogenetic analyses consistently grouped all 74 SSU sequence types with publicly available reference sequences representing E. coli, E. bovis and E. hartmanni (see Fig. 1), with strong support ( $\mathrm{pp}=0.95-1.00$ ), to the exclusion of all sequences representing other recognised Entamoeba species, their subtypes, and ribosomal lineages.

\section{Cyclospora}

Sequencing of all amplicons (six and 30 from humans and mountain gorilla samples, respectively) identified that none of the samples tested contained Cyclospora DNA detectable by PCR. Based on sequence comparisons with data available on GenBank, genetic data determined herein indicated that amplicons were the result of the amplification of SSU from passerine Eimeria species (data not shown).

\section{Discussion}

The present study genetically classified Cryptosporidium, Giardia, and Entamoeba in individual faecal samples from three potential host groups in and around BINP. Our systematic molecular analysis categorised all samples by comparison with reference data available in the GenBank database. The data provide no clear evidence for multiple inter-species transmission cycles (i.e. protists with the same sequence types shared among mountain gorillas, humans, or livestock). A fourth, Cyclospora, appears absent, or was below the limit of detection, from the 203 samples tested. The only sequence derived from multiple host groups was amplified from DNA extracted from an individual faecal sample from a human (fr. Buhoma) and a gorilla (fr. South, Group Bushaho) (c.10 km apart based on geographical coordinates; see Table 1). Comparison of this sequence type with public data indicated it was from an Entamoeba sample, which was 26 nucleotides or 4\% different, over $631 \mathrm{bp}$, from an E. coli sequence (AB4444953). In contrast to these findings, previous epidemiological studies, on a broad range of pathogens, have frequently inferred cross-species transmission to be likely in the case of Cryptosporidium [24], Giardia [25], Escherichia coli [26] and Encephalitozoon intestinalis [27] in Uganda and Tanzania. However, in most cases, the prevalence of infection was higher than the $1.4 \%, 2.4 \%$, and $54.7 \%$ for Cryptosporidium, Giardia and Entamoeba, respectively, determined here. Differences in prevalence of infection may be associated with the times of year samples were collected or 


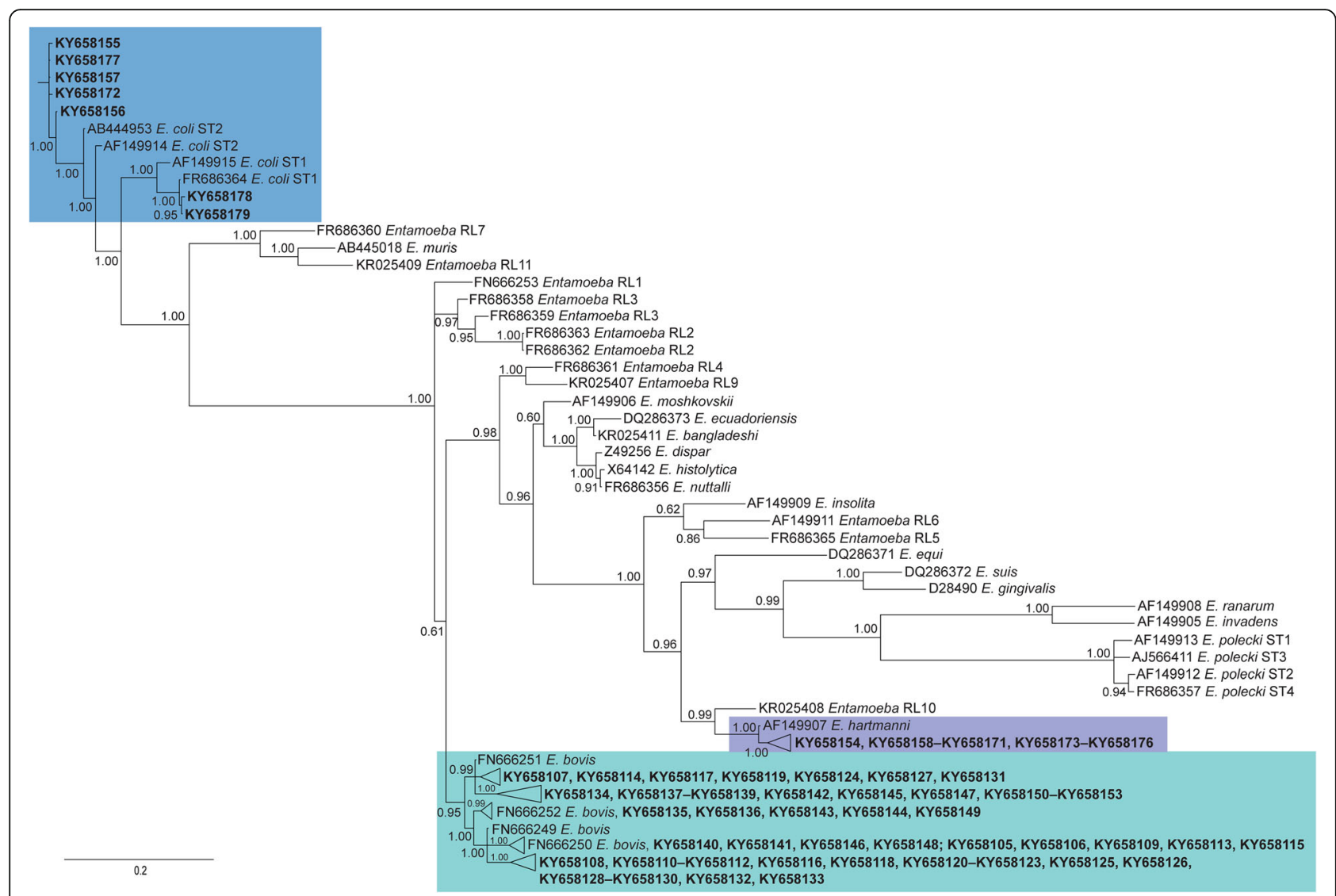

Fig. 1 The relationships between species and ribosomal/conditional lineages of Entamoeba inferred from SSU sequence data following analysis by Bayesian inference (BI). Posterior probabilities are indicated at all major nodes. New sequences generated here shown in bold

differences in local habitat. Alternatively, these findings may reflect changes in Park management practices on faecal contamination of the region by local inhabitants, researchers, tourists, and Park Wardens, and proximity to agricultural land.

Using our PCR-based approach, we genetically characterised seven samples, which were assigned to Cryptosporidium parvum, and to the genetic assemblages A, B and $\mathrm{E}$ of G. duodenalis. Cryptosporidium parvum has an extremely broad host distribution making it the greatest zoonotic risk. It is also a cause of economic losses associated with bovine cryptosporidiosis [28]. Despite detecting C. parvum here, it was not found in humans or cattle, but from a gorilla and a goat. The low prevalence (1.4 and $1.7 \%$, respectively, or $1 \%$ in all livestock) detected here may suggest a relatively low risk of transmission to humans and other mammals in/around BINP. Nonetheless, previous studies in this area have detected C. parvum from $11 \%$ of 100 gorillas [29], 38\% of 50 cattle [30] and $8 \%$ of 62 humans [31] tested. In addition, in regions $<200 \mathrm{~km}$ from BINP, Salyer et al. [24] found the prevalence of infection in humans, non-human primates (NHP) and livestock as high as $32.4 \%, 11.1 \%$, and $2.2 \%$, respectively. These discrepancies highlight the need for further investigations of the presence and distribution of Cryptosporidium genotypes. Not only are these investigations essential to determine the potential significance of different host groups as sources, reservoirs, and amplifiers of Cryptosporidium, but also to establish which C. parvum transmission cycles occur naturally (e.g. human-to-human, animal-to-human and vice versa, and animal-to-animal) [32]. Understanding the underlying forces behind host-parasite relationships is important, particularly in areas such as BINP that are surrounded by extreme ecological imbalances (i.e. high human and livestock densities, both with low-quality health services), as a reduction in habitat can lead to changes in host density that result in alterations to host-parasite dynamics.

Of the two Cryptosporidium sequence types described here, only one has been reported previously. The single SSU sequence type (KY658104) appears to be distributed globally, having been recorded previously in animal hosts other than goats globally (e.g. [33-35]). While this sequence type has not been reported from humans, it has been characterised from cattle [34] and buffalo 
(Maurya PS. et al., unpublished), both of which are important livestock species. Given (i) the impoverished economic status of the human population surrounding BINP and the reliance on livestock animals to reduce chronic malnutrition, increase food security, and generate an alternate source of income, (ii) the economic losses that may result from bovine cryptosporidiosis, and (iii) the limited genetic information for parasites from herds in the region, 'tracking' Cryptosporidium spatially and temporally in Uganda is necessary for the future prevention and control of disease.

Based on gp60 data, a single sequence was characterised as genotype IId of $C$. parvum, subgenotype IIdA23G2 (KY658103). This subgenotype and sequence type are, to the best of our knowledge, both new records. The genotype is also a new record for Uganda. The IId genotype has been reported from humans (e.g. [36-40]) and livestock animals (e.g. [41-50]), globally. Recently, genotype IId has been recorded in NHP from China [51], albeit with a different subgenotype (IIdA15G2R1). Consequently, genotype IId, along with IIa, is considered one of the two zoonotic subtype groups of C. parvum [52]. The presence of this genotype highlights the potential occurrence of zoonotic transmission in the region; however, further studies are needed to confirm transmission patterns of this genotype in the region.

From the five samples that tested positive in PCR for G. duodenalis, we did not find polymorphic nucleotide positions in tpi, $g d h$, or $b g$ sequence types as has been reported previously (e.g. [53, 54]). Also in contrast to previous multilocus genotyping studies (e.g. $[55,56])$, there was no discrepancy in assemblage assignment among the four genes for the five samples examined herein, albeit variable amplification success among genes prohibited phylogenetic analysis of a concatenated dataset. The sample characterised and assigned to assemblage A, sub-assemblage AII, based on sequence data from $g d h, b g$ and SSU (KY658185, KY658181 and KY658188, respectively), and recorded here from a human, grouped with G. duodenalis genotypes reported from humans (e.g. [57-64]), wild and domestic animals (including cattle) (e.g. [65-68]) and water samples (e.g. $[69,70])$ from around the world. Samples from a human assigned here to assemblage B, subassemblage BIV, based on sequence data from $g d h$ and SSU (KY658183 and KY658187, respectively), grouped with G. duodenalis genotypes reported from humans from Australia, Brazil, the Netherlands and USA [71-73], and wild and domestic animals (including NHP) [74-77], globally. The second sample assigned to assemblage $\mathrm{B}$, subassemblage BIV, based on phylogenetic analysis of sequence data from $b g$ and SSU (KY658180 and KY658186, respectively), grouped with G. duodenalis SSU genotypes reported from humans from Australia, the Netherlands and USA [73, 78] and wild and domestic animals (including NHP) from Spain and Colombia [76, 77], globally. The corresponding $b g$ sequence is new. Samples from cattle assigned to assemblage $\mathrm{E}$ on the basis of genetic data from tpi, gdh and $b g$ (KY658190, KY658184 and KY658182, respectively), grouped with tpi and $g d h$ genotypes reported previously from cattle in Bangladesh, China and USA [67, 79, 80], and NHP from China [51]. The corresponding $b g$ sequence is new, as is the tpi AII sequence type (KY658189) recorded here from cattle.

Giardia duodenalis responsible for the human disease is most commonly linked to assemblages A and B [81, 82], while samples from livestock are typically linked to E. Of the subassemblages/genotypes described, AII, BIII, and BIV were considered specific to humans (see [83]). Nonetheless, multiple, related genotypes within each of these two assemblages have been detected in a range of animals (see $[80,84-86])$. Our findings are consistent with this. Although it is not possible to illustrate the direct sharing of protist species among host groups using identical sequences, our finding of the G. duodenalis sub-assemblage AII in both a human and cattle indicates the potential for human-to-livestock transmission (based on published data; i.e. [87]).

The remaining samples positive in PCR were phylogenetically closest to Entamoeba. Our results showed an overall prevalence of $54.7 \%$ for Entamoeba sequence types from the 203 faecal samples, and 9.1\%, 55.9\%, $80.0 \%$ and $60.0 \%$ in human, mountain gorilla, cattle and goat faecal samples (or $68.6 \%$ of livestock faecal samples), respectively. The overall prevalence in mountain gorillas is comparable ( $55.9 \%$ in 68 samples vs $48.5 \%$ in 70 samples) to figures previously reported from Rwanda [88], despite the authors using microscopic examination and centrifugal flotation techniques. Although not the preferred method of identification [13], Sleeman et al. [88] also characterised Entamoeba samples to the level of species based on cyst and trophozoite morphology, detecting E. coli, E. hartmanni and E. histolytica in $20 \%$, $27 \%$ and $1.4 \%$ of samples tested. Here, despite using what is the more sensitive/specific technique for the detection and classification of protists in faecal samples, we are 'technically' unable to classify all 74 sequence types to the level of species based on the criteria of Jacob et al. [13], having amplified $<80 \%$ of SSU gene (i.e. 539580 of $c .1400 \mathrm{nt}$ ). However, based on initial sequence comparisons, and our phylogenetic analysis (see Fig. 1), which includes reference sequences representing 17 recognised species and 11 published ribosomal lineages, we interpret 72 new sequence types with caution and classify them as variants (rather than species/subtypes/ ribosomal lineages/conditional lineages) of E. bovis, $E$. coli or E. hartmanni. The two remaining sequence types were detected from faecal samples from goats 
(KY658141 and KY658143) from Kanyamisinga and Aidah-Rugira (respectively) and were $100 \%$ identical to two sequences for E. bovis (FN666250 and FN666252 from sheep and caribou, respectively) [89] over $546 \mathrm{nu}$ cleotides. Again, we use caution in this interpretation. Regardless, just two sequence types were shared among host groups, and (typically) these species are not considered pathogenic.

In addition to detecting the target parasites, many samples positive in PCR and sent for sequencing returned results linking amplicons to bacteria or passerine Eimeria (data not shown). This finding highlights the advantages of using phenetic-based approaches, i.e. RFLP, single-strand conformation polymorphism (SSCP), or restriction endonuclease fingerprinting-SSCP, coupled with sequencing to screen large numbers of samples by detecting point mutations, group samples by profile and only sequence representative amplicons. Mutation scanning can, therefore, be a sensitive and powerful tool for the direct analysis of subtle genetic variation within and among populations of protists isolated from animals and the environment.

\section{Conclusions}

The present study has provided a snapshot of the occurrence and genetic make-up of Cryptosporidium, Giardia, Entamoeba and Cyclospora in mammals in BINP. The genetic analyses indicated that $54.6 \%$ of the 203 samples contained Cryptosporidium, Giardia or Entamoeba that matched species, genotypes or assemblages with the potential to infect humans, mountain gorillas, and livestock species. In addition, 76 new sequence records were identified. As nothing is known about the zoonotic/zooanthroponotic potential of protist samples with these sequences, future work should focus on wider epidemiological investigations of these genetic types together with continued surveillance of protists in humans, other mammals, the environment, and water in this highly impoverished area.

\section{Additional file}

Additional file 1: Table S1. Sequence data determined in this study, together with epidemiological information. (DOCX $15 \mathrm{~kb}$ )

\footnotetext{
Abbreviations

AIC: Akaike information criteria; bg: beta-giardin gene; BI: Bayesian inference; BINP: Bwindi Impenetrable National Park; CTPH: Conservation through Public Health; EDTA: Ethylenediaminetetraacetic acid; gdh: Glutamate dehydrogenase gene; gDNA: Total genomic DNA; gp60: 60 kDa glycoprotein gene; ID: Infectious diseases; MCMC: Monte Carlo Markov chain; NHP: Nonhuman primate; PBS: Phosphate buffered saline; Pp: Posterior probability; RFLP: Restriction fragment length polymorphism; RVC: Royal Veterinary College; SSCP: Single-strand conformation polymorphism; SSU: Small subunit of the ribosomal DNA; TBE: Tris, boric acid, ethylenediaminetetraacetic acid buffer; tpi: triosephosphate isomerase gene
}

\section{Acknowledgements}

We gratefully acknowledge the Uganda Wildlife Authority, the Uganda National Council for Science and Technology, Mbarara University of Science and Technology and the Zoological Society of London for their permission to conduct the study. We also thank Stephen Rubanga, Saul Ngabirano, Alex Ngabirano and the remaining members of the Conservation through Public Health for their assistance during the fieldwork. We gratefully acknowledge James Stephenson for technical assistance. Further thanks are due to Drs Rachel Chalmers and Kristin Elwin from the Cryptosporidium Reference Unit for providing Cryptosporidium and Giardia reference materials. RVC has assigned this manuscript the reference PPS_01506.

\section{Funding}

This study was funded by the Royal Veterinary College and the Zoological Society of London as part of the Masters in Wild Animal Health course, with support from the Zebra Foundation. The Erasmus Programme supports IM.

\section{Availability of data and materials}

Relevant data are within the paper and its Additional file. Also, raw sequence data analysed for this article were deposited in the GenBank database under the accession numbers KY658103-KY658190.

\section{Authors' contributions}

MU and GKZ collected the samples. MU and KH extracted the genomic DNA. MU, YTY, ER, and IM carried out the molecular laboratory work. MN assisted with the molecular work, performed the phylogenetic analyses, and drafted the manuscript with assistance from DB. MF, GKZ, and DB participated in the experimental design. All authors read and approved the final manuscript.

\section{Ethics approval and consent to participate}

The Uganda Wildlife Authority, the Uganda National Council for Science and Technology, the Institutional Review Board at the Mbarara University of Science and Technology and the Ethical Review Committees of the Zoological Society of London and the Royal Veterinary College approved this study. All human participants gave their written informed consent to be involved in this study. For individuals $<18$ years of age, written consent was provided by a parent or guardian. Once collected by health technicians from Bwindi Community Hospital and Kayonza Health Center III, Uganda, all human samples were anonymized. Gorilla faecal samples were collected from night nests by MU and GK-Z after gorillas had left the area: there was no direct contact with the gorillas at any time. Prior, written informed consent was obtained from farmers before faecal samples were collected from livestock animals on private farms. All faecal samples were transported to the Royal Veterinary College, London, United Kingdom in strict accordance with the Importation of Animal Pathogens Order Permit (No: AHZ/2034/2001/2), issued by the UK Department for Environment, Food, and Rural Affairs.

\section{Consent for publication}

All human participants gave their written informed consent for data from this work to be published. For individuals $<18$ years of age, written consent was provided by a parent or guardian. Written consent was obtained from farmers for data derived from livestock to be published.

\section{Competing interests}

The authors declare that they have no competing interests.

\section{Publisher's Note}

Springer Nature remains neutral with regard to jurisdictional claims in published maps and institutional affiliations.

\section{Author details}

'Department of Pathobiology and Population Sciences, Royal Veterinary College, University of London, Hatfield, UK. ${ }^{2}$ Conservation through Public Health, Plot 3 Mapera Lane, Uringi Crescent, Entebbe, Uganda. 
Received: 14 March 2017 Accepted: 11 July 2017

\section{Published online: 18 July 2017}

\section{References}

1. Messenger AM, Barnes AN, Gray GC. Reverse zoonotic disease transmission (zooanthroponosis): a systematic review of seldom-documented human biological threats to animals. PLoS One. 2014;9(2):e89055

2. de Graaf DC, Vanopdenbosch E, Ortega-Mora LM, Abbassi H, Peeters JE. A review of the importance of cryptosporidiosis in farm animals. Int J Parasitol. 1999;29(8):1269-87.

3. Leroy EM, Rouquet P, Formenty P, Souquière S, Kilbourne A, Froment JM, et al. Multiple Ebola virus transmission events and rapid decline of central African wildlife. Science. 2004;303(5656):387-90.

4. Cully JF Jr, Barnes AM, Quan TJ, Maupin G. Dynamics of plague in a Gunnison's prairie dog colony complex from New Mexico. J Wildl Dis. 1997; 33(4):706-19.

5. Ginsberg JR, Mace GM, Albon S. Local extinction in a small and declining population: wild dogs in the Serengeti. Proc R Soc Lond Ser B. 1995;262: 221-8.

6. Robbins M, Gray M, Kümpel N, Lanjouw A, Maisels F, Mugisha A, et al. Gorilla beringei ssp. beringei. The IUCN Red List of Threatened Species 2008 : e.T39999A10292321 2008 [cited 2016 07/11/2016].

7. Gray M, Fawcett K, Basabose A, Cranfield M, Vigilant L, Roy J, et al. Virunga Massif mountain gorilla census -2010 summary. report. 2011

8. Robbins MM, Roy J, Wright E, Kato R, Kabano P, Basabose A, et al. Bwindi mountain gorilla census 2011- summary of results. 2011.

9. Cranfield MR. Mountain gorilla research: the risk of disease transmission relative to the benefit from the perspective of ecosystem health. Am J Primatol. 2008;70(8):751-4.

10. Guerrera W, Sleeman JM, Ssebide BJ, Pace LB, Ichinose TY, Reif JS. Medical survey of the local human population to determine possible health risks to the mountain gorillas of Bwindi impenetrable Forest National Park. Uganda Int J Primatol. 2003;24:197-207.

11. Jex AR, Smith HV, Monis PT, Campbell BE, Gasser RB. Cryptosporidium biotechnological advances in the detection, diagnosis and analysis of genetic variation. Biotechnol Adv. 2008;26(4):304-17.

12. Monis PT, Andrews RH, Mayrhofer G, Ey PL. Genetic diversity within the morphological species Giardia intestinalis and its relationship to host origin. Infect Genet Evol. 2003;3(1):29-38.

13. Jacob AS, Busby EJ, Levy AD, Komm N, Clark CG. Expanding the Entamoeba universe: new hosts yield novel ribosomal lineages. J Eukaryot Microbiol. 2016;63(1):69-78.

14. Ortega YR, Sanchez R. Update on Cyclospora cayetanensis, a food-borne and waterborne parasite. Clin Microbiol Rev. 2010;23(1):218-34.

15. Edgar RC. MUSCLE: a multiple sequence alignment method with reduced time and space complexity. BMC Bioinformatics. 2004;5:113.

16. Edgar RC. MUSCLE: multiple sequence alignment with high accuracy and high throughput. Nucleic Acids Res. 2004;32(5):1792-7.

17. Hall TA. Bio edit: a user-friendly biological sequence alignment editor and analysis program for windows 95/98/NT. Nucleic Acids Symp Ser. 1999;41: 95-8

18. Huelsenbeck JP, Ronquist F. MRBAYES: Bayesian inference of phylogenetic trees. Bioinformatics. 2001;17(8):754-5.

19. Ronquist F, Huelsenbeck JP. MrBayes 3: Bayesian phylogenetic inference under mixed models. Bioinformatics. 2003;19(12):1572-4.

20. Hurvich CM, Tsai A. Regression and time series model selection in small samples. Biometrika. 1989;76(2):297-307.

21. Posada G, Crandall KA. Modeltest: testing the model of DNA substitution. Bioinformatics. 1998;14(9):817-8.

22. Sulaiman IM, Hira PR, Zhou L, Al-Ali FM, Al-Shelahi FA, Shweiki HM, et al. Unique endemicity of cryptosporidiosis in children in Kuwait. J Clin Microbiol. 2005;43(6):2805-9.

23. Chalmers RM, Robinson G, Elwin K, Hadfield SJ, Xiao L, Ryan UM, et al. Cryptosporidium sp. rabbit genotype, a newly identified human pathogen. Emerg Infect Dis. 2009;15(5):829-30.

24. Salyer SJ, Gillespie TR, Rwego IB, Chapman CA, Goldberg TL. Epidemiology and molecular relationships of Cryptosporidium spp. in people, primates, and livestock from western Uganda. PLoS Negl Trop Dis. 2012;6(4):e1597.

25. Johnston AR, Gillespie TR, Rwego IB, McLachlan TL, Kent AD, Goldberg TL. Molecular epidemiology of cross-species Giardia duodenalis transmission in western Uganda. PLoS Negl Trop Dis. 2010;4(5):e683.
26. Rwego IB, Gillespie TR, Isabirye-Basuta G, Goldberg TL. High rates of Escherichia coli transmission between livestock and humans in rural Uganda. J Clin Microbiol. 2008;46(10):3187-91.

27. Graczyk TK, Bosco-Nizeyi J, da Silva AJ, Moura IN, Pieniazek NJ, Cranfield MR, et al. A single genotype of Encephalitozoon intestinalis infects free-ranging gorillas and people sharing their habitats in Uganda. Parasitol Res. 2002; 88(10):926-31.

28. Santín M, Trout JM, Fayer R. A longitudinal study of cryptosporidiosis in dairy cattle from birth to 2 years of age. Vet Parasitol. 2008;155(1-2):15-23.

29. Graczyk TK, DaSilva AJ, Cranfield MR, Nizeyi JB, Kalema GR, Pieniazek NJ. Cryptosporidium parvum genotype 2 infections in free-ranging mountain gorillas (Gorilla gorilla beringei) of the Bwindi impenetrable National Park Uganda. Parasitol Res. 2001;87(5):368-70.

30. Nizeyi JB, Cranfield MR, Graczyk TK. Cattle near the Bwindi impenetrable National Park, Uganda, as a reservoir of Cryptosporidium parvum and Giardia duodenalis for local community and free-ranging gorillas. Parasitol Res. 2002; 88(4):380-5.

31. Nizeyi JB, Sebunya D, Dasilva AJ, Cranfield MR, Pieniazek NJ, Graczyk TK. Cryptosporidiosis in people sharing habitats with free-ranging mountain gorillas (Gorilla gorilla beringei) Uganda. Am J Trop Med Hyg. 2002;66(4):442-4.

32. Smith HV, Cacciò SM, Cook N, Nichols RA, Tait A. Cryptosporidium and Giardia as foodborne zoonoses. Vet Parasitol. 2007;149(1-2):29-40.

33. Feng $Y$, Alderisio KA, Yang W, Blancero LA, Kuhne WG, Nadareski CA, et al. Cryptosporidium genotypes in wildlife from a New York watershed. Appl Environ Microbiol. 2007;73(20):6475-83.

34. Karanis P, Eiji T, Palomino L, Boonrod K, Plutzer J, Ongerth J, et al. First description of Cryptosporidium bovis in Japan and diagnosis and genotyping of Cryptosporidium spp. in diarrheic pre-weaned calves in Hokkaido. Vet Parasitol. 2010;169(3-4):387-90.

35. Twomey DF, Barlow AM, Bell S, Chalmers RM, Elwin K, Giles M, et al. Cryptosporidiosis in two alpaca (Lama pacos) holdings in the south-west of England. Vet J. 2008;175(3):419-22.

36. $\mathrm{Ng}$ J, MacKenzie B, Ryan U. Longitudinal multi-locus molecular characterisation of sporadic Australian human clinical cases of cryptosporidiosis from 2005 to 2008. Exp Parasitol. 2010;125(4):348-56.

37. Abe N, Matsubayashi M, Kimata I, Iseki M. Subgenotype analysis of Cryptosporidium parvum isolates from humans and animals in Japan using the 60-kDa glycoprotein gene sequences. Parasitol Res. 2006;99(3):303-5.

38. Adamu H, Petros B, Zhang G, Kassa H, Amer S, Ye J, et al. Distribution and clinical manifestations of Cryptosporidium species and subtypes in HIV/AIDS patients in Ethiopia. PLoS Negl Trop Dis. 2014;8(4):e2831.

39. Zintl A, Ezzaty-Mirashemi M, Chalmers RM, Elwin K, Mulcahy G, Lucy FE, et al. Longitudinal and spatial distribution of GP60 subtypes in human cryptosporidiosis cases in Ireland. Epidemiol Infect. 2011;139:1945-55.

40. O'Brien E, McInnes L, Ryan U. Cryptosporidium GP60 genotypes from humans and domesticated animals in Australia North America and Europe. Exp Parasitol. 2008;118:118-21.

41. Muhid A, Robertson I, Ng J, Ryan U. Prevalence of and management factors contributing to Cryptosporidium sp. infection in pre-weaned and postweaned calves in Johor, Malaysia. Exp Parasitol. 2011;127(2):534-8.

42. Amer S, Zidan S, Adamu H, Ye J, Roellig D, Xiao L, et al. Prevalence and characterization of Cryptosporidium spp. in dairy cattle in Nile River delta provinces, Egypt. Exp Parasitol. 2013;135(3):518-23.

43. Li F, Wang H, Zhang Z, Li J, Wang C, Zhao J, et al. Prevalence and molecular characterization of Cryptosporidium spp. and Giardia duodenalis in dairy cattle in Beijing, China. Vet Parasitol. 2016;219:61-5.

44. Broglia A, Reckinger S, Cacciò SM, Nöckler K. Distribution of Cryptosporidium parvum subtypes in calves in Germany. Vet Parasitol. 2008;154(1-2):8-13.

45. Tzanidakis N, Sotiraki S, Claerebout E, Ehsan A, Voutzourakis N, Kostopoulou $D$, et al. Occurrence and molecular characterization of Giardia duodenalis and Cryptosporidium spp. in sheep and goats reared under dairy husbandry systems in Greece. Parasite. 2014;21:45.

46. Geurden T, Thomas P, Casaert S, Vercruysse J, Claerebout E. Prevalence and molecular characterisation of Cryptosporidium and Giardia in lambs and goat kids in Belgium. Vet Parasitol 2008; 155 (1-2):142-5.

47. Helmy YA, Krücken J, Nöckler K, von Samson-Himmelstjerna G, Zessin KH. Molecular epidemiology of Cryptosporidium in livestock animals and humans in the Ismailia province of Egypt. Vet Parasitol. 2013;193(1-3):15-24.

48. Qi M, Cai J, Wang R, Li J, Jian F, Huang J, et al. Molecular characterization of Cryptosporidium spp. and Giardia duodenalis from yaks in the central western region of China. BMC Microbiol. 2015;15:108. 
49. Galuppi R, Piva S, Castagnetti C, lacono E, Tanel S, Pallaver F, et al. Epidemiological survey on Cryptosporidium in an equine Perinatology unit. Vet Parasitol. 2015;210(1-2):10-8.

50. Vieira PM, Mederle N, Lobo ML, Imre K, Mederle O, Xiao L, et al. Molecular characterisation of Cryptosporidium (Apicomplexa) in children and cattle in Romania. Folia Parasitol (Praha). 2015;62:002

51. Du SZ, Zhao GH, Shao JF, Fang YQ, Tian GR, Zhang LX, et al. Cryptosporidium spp., Giardia intestinalis, and Enterocytozoon bieneusi in captive non-human primates in Qinling Mountains. Korean J Parasitol. 2015; 53(4):395-402

52. Plutzer J, Karanis P. Genetic polymorphism in Cryptosporidium species: an update. Vet Parasitol. 2009;165:187-99.

53. Cacciò SM, Beck R, Lalle M, Marinculic A, Pozio E. Multilocus genotyping of Giardia duodenalis reveals striking differences between assemblages a and B. Int J Parasitol. 2008;38(13):1523-31.

54. Lebbad M, Mattsson JG, Christensson B, Ljungström B, Backhans A, Andersson JO, et al. From mouse to moose: multi locus genotyping of Giardia isolates from various animal species. Vet Parasitol. 2010;168(3-4):231-9.

55. Read CM, Monis PT, Thompson RC. Discrimination of all genotypes of Giardia duodenalis at the glutamate dehydrogenase locus using PCR-RFLP. Infect Genet Evol. 2004;4(2):125-30.

56. Levecke B, Geldhof P, Claerebout E, Dorny P, Vercammen F, Cacciò SM, et al. Molecular characterisation of Giardia duodenalis in captive non-human primates reveals mixed assemblage a and $B$ infections and novel polymorphisms. Int J Parasitol. 2009;39(14):1595-601.

57. Wegayehu T, Karim MR, Li J, Adamu H, Erko B, Zhang L, et al. Multilocus genotyping of Giardia duodenalis isolates from children in Oromia special zone, central Ethiopia. BMC Microbiol. 2016;16:89.

58. de Lucio A, Martinez-Ruiz R, Merino FJ, Bailo B, Aguilera M, Fuentes I, et al. Molecular genotyping of Giardia duodenalis isolates from symptomatic individuals attending two major public hospitals in Madrid Spain. PLoS One. 2015;10(12):e0143981.

59. Ferreira FS, Centeno-Lima S, Gomes J, Rosa F, Rosado V, Parreira R, et al. Molecular characterization of Giardia duodenalis in children from the Cufada lagoon Natural Park Guinea-Bissau. Parasitol Res. 2012;111(5):2173-7.

60. Laishram S, Kannan A, Rajendran P, Kang G, Ajjampur SS. Mixed Giardia duodenalis assemblage infections in children and adults in South India. Epidemiol Infect. 2012;140(11):2023-7.

61. Kosuwin R, Putaporntip C, Pattanawong U, Jongwutiwes S. Clonal diversity in Giardia duodenalis isolates from Thailand: evidences for intragenic recombination and purifying selection at the beta giardin locus. Gene. 2010; 449(1-2):1-8.

62. Bonhomme J, Le Goff L, Lemée V, Gargala G, Ballet JJ, Favennec L. Limitations of tpi and $\mathrm{bg}$ genes sub-genotyping for characterization of human Giardia duodenalis isolates. Parasitol Int. 2011;60(3):327-30.

63. Cacciò SM, De Giacomo M, Pozio E. Sequence analysis of the $\beta$-giardin gene and development of a polymerase chain reaction-restriction fragment length polymorphism assay to genotype Giardia duodenalis cysts from human faecal samples. Int J Parasitol. 2002;32(8):1023-30.

64. Yong TS, Park SJ, Hwang UW, Yang HW, Lee KW, Min DY, et al. Genotyping of Giardia lamblia isolates from humans in China and Korea using ribosomal DNA sequences. J Parasitol. 2000;86(4):887-91.

65. Gómez-Couso H, Ortega-Mora LM, Aguado-Martínez A, Rosadio-Alcántara R, Maturrano-Hernández L, Luna-Espinoza L, et al. Presence and molecular characterisation of Giardia and Cryptosporidium in alpacas (Vicugna pacos) from Peru. Vet Parasitol. 2012;187(3-4):414-20.

66. Geurden T, Goossens E, Levecke B, Vercammen F, Vercruysse J, Claerebout E. Occurrence and molecular characterization of Cryptosporidium and Giardia in captive wild ruminants in Belgium. J Zoo Wildl Med. 2009;40(1):126-30.

67. Wang $H$, Zhao G, Chen G, Jian F, Zhang S, Feng C, et al. Multilocus genotyping of Giardia duodenalis in dairy cattle in Henan China. PLoS One. 2014;9(6):e100453.

68. Santín M, Dargatz D, Fayer R. Prevalence of Giardia duodenalis assemblages in weaned cattle on cow-calf operations in the United States. Vet Parasitol. 2012;183(3-4):231-6

69. Fernandes LN, de Souza PP, de Araújo RS, Razzolini MT, Soares RM, Sato MI, et al. Detection of assemblages a and B of Giardia duodenalis in water and sewage from São Paulo state Brazil. J Water Health. 2011;9(2):361-7.

70. Koloren Z, Seferoğlu O, Karanis P. Occurency of Giardia duodenalis assemblages in river water sources of Black Sea Turkey. Acta Trop. 2016;164:337-44
71. Souza SL, Gennari SM, Richtzenhain LJ, Pena HF, Funada MR, Cortez A, et al. Molecular identification of Giardia duodenalis isolates from humans, dogs, cats and cattle from the state of São Paulo, Brazil, by sequence analysis of fragments of glutamate dehydrogenase ( $g d h)$ coding gene. Vet Parasitol. 2007;149(3-4):258-64.

72. Lasek-Nesselquist E, Welch DM, Thompson RC, Steuart RF, Sogin ML. Genetic exchange within and between assemblages of Giardia duodenalis. J Eukaryot Microbiol. 2009;56(6):504-18.

73. van Keulen H, Homan WL, Erlandsen SL, Jarroll EL. A three nucleotide signature sequence in small subunit rRNA divides human Giardia in two different genotypes. J Eukaryot Microbiol. 1995;42(4):392-4

74. Prystajecky N, Tsui CK, Hsiao WW, Uyaguari-Diaz MI, Ho J, Tang P, et al. Giardia spp. are commonly found in mixed assemblages in surface water, as revealed by molecular and whole-genome characterization. Appl Environ Microbiol. 2015:81(14):4827-34.

75. Soares RM, de Souza SL, Silveira LH, Funada MR, Richtzenhain LJ, Gennari SM. Genotyping of potentially zoonotic Giardia duodenalis from exotic and wild animals kept in captivity in Brazil. Vet Parasitol 2011; 180 (3-4):344-8.

76. Martinez-Diaz RA, Sansano-Maestre J, Martinez-Herrero Mdel C, PonceGordo F, Gomez-Munoz MT. Occurrence and genetic characterization of Giardia duodenalis from captive nonhuman primates by multi-locus sequence analysis. Parasitol Res. 2011;109(3):539-44.

77. Santín M, Cortés Vecino JA, Fayer R. A large scale molecular study of Giardia duodenalis in horses from Colombia. Vet Parasitol. 2013;196(1-2):31-6.

78. Thompson RC, Hopkins RM, Homan WL. Nomenclature and genetic groupings of Giardia infecting mammals. Parasitol Today. 2000;16(5):210-3.

79. Ehsan AM, Geurden T, Casaert S, Parvin SM, Islam TM, Ahmed UM, et al. Assessment of zoonotic transmission of Giardia and Cryptosporidium between cattle and humans in rural villages in Bangladesh. PLoS One. 2015: 10(2):e0118239.

80. Feng Y, Ortega Y, Cama V, Terrel J, Xiao L. High intragenotypic diversity of Giardia duodenalis in dairy cattle on three farms. Parasitol Res. 2008;103(1): 87-92.

81. Mayrhofer G, Andrews RH, Ey PL, Chilton NB. Division of Giardia isolates from humans into two genetically distinct assemblages by electrophoretic analysis of enzymes encoded at 27 loci and comparison with Giardia muris. Parasitology 1995; 111(1):11-17.

82. Monis PT, Mayrhofer G, Andrews RH, Homan WL, Limper L, Ey PL. Molecular genetic analysis of Giardia intestinalis isolates at the glutamate dehydrogenase locus. Parasitology. 1996;112(1):1-12.

83. Cacciò SM, Ryan U. Molecular epidemiology of giardiasis. Mol Biochem Parasitol. 2008:160(2):75-80.

84. Sulaiman IM, Fayer R, Bern C, Gilman RH, Trout JM, Schantz PM, et al. Triosephosphate isomerase gene characterization and potential zoonotic transmission of Giardia duodenalis. Emerg Infect Dis. 2003;9(11):1444-52.

85. Traub RJ, Monis PT, Robertson I, Irwin P, Mencke N, Thompson RC. Epidemiological and molecular evidence supports the zoonotic transmission of Giardia among humans and dogs living in the same community. Parasitology. 2004;128(Pt 3):253-62.

86. Lasek-Nesselquist E, Bogomolni AL, Gast RJ, Welch DM, Ellis JC, Sogin ML, et al. Molecular characterization of Giardia intestinalis haplotypes in marine animals: variation and zoonotic potential. Dis Aquat Org. 2008;81(1):39-51.

87. Monis PT, Cacciò SM, Thompson RC. Variation in Giardia: towards a taxonomic revision of the genus. Trends Parasitol. 2009;25(2):93-100.

88. Sleeman JM, Meader LL, Mudakikwa AB, Foster JW, Patton S. Gastrointestinal parasites of mountain gorillas (Gorilla gorilla beringei) in the Parc national des Volcans Rwanda. J Zoo Wildl Med. 2000;31(3):322-8.

89. Stensvold CR, Lebbad M, Clark CG. Genetic characterisation of uninucleated cyst-producing Entamoeba spp. from ruminants. Int J Parasitol. 2010;40(7): $775-8$.

90. Li G, Xiao S, Zhou R, Li W, Wadeh H. Molecular characterization of Cyclospora-like organism from dairy cattle. Parasitol Res. 2007;100(5):955-61.

91. Sulaiman IM, Ortega Y, Simpson S, Kerdahi K. Genetic characterization of human-pathogenic Cyclospora cayetanensis parasites from three endemic regions at the 185 ribosomal RNA locus. Infect Genet Evol. 2014;22:229-34.

92. Xiao L, Morgan UM, Limor J, Escalante A, Arrowood M, Shulaw W, et al. Genetic diversity within Cryptosporidium parvum and related Cryptosporidium species. Appl Environ Microbiol. 1999;65(8):3386-91.

93. Morgan UM, Constantine CC, Forbes DA, Thompson RC. Differentiation between human and animal isolates of Cryptosporidium parvum using rDNA sequencing and direct PCR analysis. J Parasitol. 1997;83(5):825-30. 
94. Peng MM, Matos O, Gatei W, Das P, Stantic-Pavlinic M, Bern C, et al. A comparison of Cryptosporidium subgenotypes from several geographic regions. J Eukaryot Microbiol. 2001;48:28S-31S.

95. Glaberman S, Moore JE, Lowery CJ, Chalmers RM, Sulaiman I, Elwin K, et al. Three drinking-water-associated cryptosporidiosis outbreaks Northern Ireland. Emerg Infect Dis. 2002:8(6):631-3.

96. Alves M, Xiao L, Sulaiman I, Lal AA, Matos O, Antunes F. Subgenotype analysis of Cryptosporidium isolates from humans, cattle, and zoo ruminants in Portugal. J Clin Microbiol. 2003;41(6):2744-7.

97. Lalle M, Pozio E, Capelli G, Bruschi F, Crotti D, Cacciò SM. Genetic heterogeneity at the $\beta$-giardin locus among human and animal isolates of Giardia duodenalis and identification of potentially zoonotic subgenotypes. Int J Parasitol. 2005;35(2):207-13.

98. Appelbee AJ, Frederick LM, Heitman TL, Olson ME. Prevalence and genotyping of Giardia duodenalis from beef calves in Alberta Canada. Vet Parasitol. 2003;112(4):289-94.

99. Hopkins RM, Meloni BP, Groth DM, Wetherall JD, Reynoldson JA, Thompson $\mathrm{RC}$. Ribosomal RNA sequencing reveals differences between the genotypes of Giardia isolates recovered from humans and dogs living in the same locality. J Parasitol. 1997;83(1):44-51.

100. Santos HLC, Bandyopadhyay K, Bandea R, Peralta RHS, Peralta JM, Da Silva AJ. LUMINEX: a new technology for the simultaneous identification of five Entamoeba spp. commonly found in human stools. Parasit Vectors. 2013;6:69.

\section{Submit your next manuscript to BioMed Central} and we will help you at every step:

- We accept pre-submission inquiries

- Our selector tool helps you to find the most relevant journal

- We provide round the clock customer support

- Convenient online submission

- Thorough peer review

- Inclusion in PubMed and all major indexing services

- Maximum visibility for your research

Submit your manuscript at www.biomedcentral.com/submit 